\title{
Antibacterial efficacy of endodontic irrigation solutions against Enterococcus faecalis
}

\author{
Andreea Cristiana Didilescu ${ }^{1 *}$, Claudia Melchiori', Luminița Nica², Mihai Săndulescu', Adrian Băncescu ${ }^{3}$, \\ Gabriela Băncescu ${ }^{1}$ \\ From The 9th Edition of the Scientific Days of the National Institute for Infectious Diseases Prof Dr Matei Bals \\ Bucharest, Romania. 23-25 October 2013
}

\section{Background}

The anatomical complexity of dental root canals represents a major limitation for a successful endodontic treatment, due to the impossibility of complete instrumentation. Therefore, irrigations are required to facilitate removal of microorganisms. The aim of the study was to test the antimicrobial activity of different endodontic irrigants against Enterococcus faecalis growth.

\section{Methods}

Forty-one extracted single-rooted teeth were included in the present study. After content removal and autoclaving, they were divided into eight groups among which two were used as positive and negative controls. The remaining six groups were instrumented and irrigated with solutions containing $17 \%$ EDTA, sterile saline solution, and different concentrations of $\mathrm{NaOCl}$. In addition, chlorhexidine $2 \%$ was also used in three groups. Microbiological evaluation was performed after 30 minutes, and 24 hours, respectively. E faecalis strain ATCC 29212 was used for culture tests. Statistical analysis was performed using non-parametric tests.

\section{Results}

$\mathrm{NaOCl} 6 \%$ recorded statistically significant higher antibacterial effect than $\mathrm{NaOCl} 2.5 \%(\mathrm{p}<0.05)$. With this regard, no significant differences were recorded between the effects of $\mathrm{NaOCl} 6 \%$ and $\mathrm{NaOCl} 5.25 \%$. The same outcome was obtained in E faecalis growth comparisons between successive dilutions within the same group. Use of chlorhexidine $2 \%$ did not influence the results.

\footnotetext{
* Correspondence: andreea.didilescu@gmail.com

${ }^{1}$ Faculty of Dental Medicine, Carol Davila University of Medicine and Pharmacy, Bucharest, Romania

Full list of author information is available at the end of the article
}

\section{Conclusion}

The antimicrobial activity of endodontic irrigants against $E$ faecalis was improved by use of higher concentrations of $\mathrm{NaOCl}(5.25 \%$ and $6 \%)$.

\section{Authors' details}

${ }^{1}$ Faculty of Dental Medicine, Carol Davila University of Medicine and Pharmacy, Bucharest, Romania. ${ }^{2}$ Faculty of Dental Medicine, Victor Babeş University of Medicine and Pharmacy, Timişoara, Romania. ${ }^{3}$ Faculty of Medicine, Carol Davila University of Medicine and Pharmacy, Bucharest, Romania.

Published: 16 December 2013

\section{doi:10.1186/1471-2334-13-S1-P113}

Cite this article as: Didilescu et al: Antibacterial efficacy of endodontic irrigation solutions against Enterococcus faecalis. BMC Infectious Diseases 2013 13(Suppl 1):P113.

\section{() Biomed Central}

Submit your next manuscript to BioMed Central and take full advantage of:

- Convenient online submission

- Thorough peer review

- No space constraints or color figure charges

- Immediate publication on acceptance

- Inclusion in PubMed, CAS, Scopus and Google Scholar

- Research which is freely available for redistribution Submit your manuscript at
www.biomedcentral.com/submit C Biomed Central 